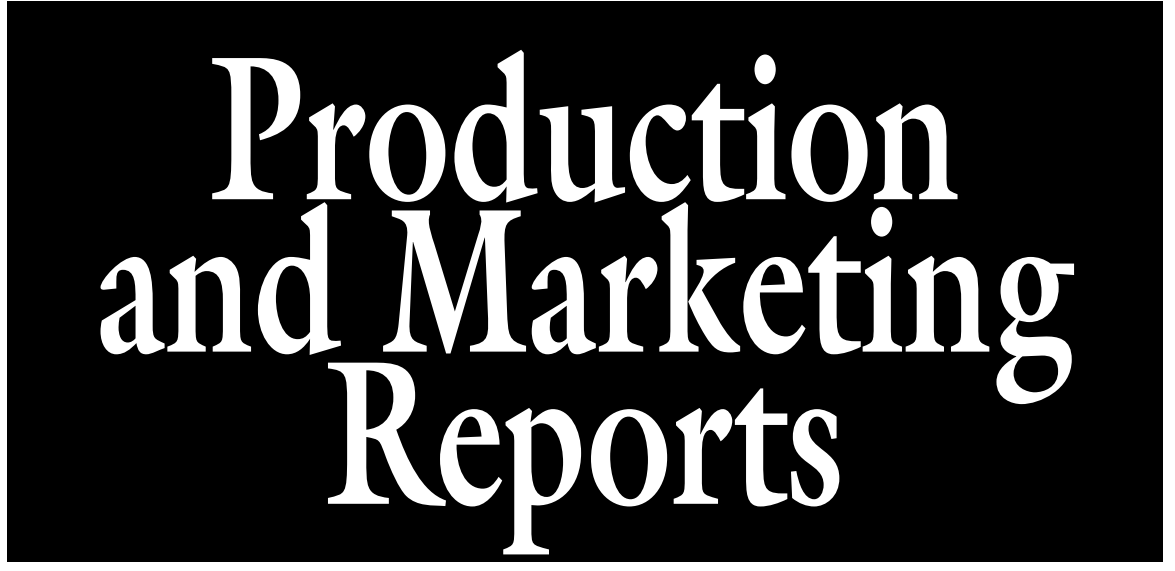

\title{
Consumer Knowledge of Nutritional Attributes of Pecans and Factors Affecting Purchasing Behavior
}

\author{
Leonardo Lombardini ${ }^{1,4}$, Tina M. Waliczek ${ }^{2}$, \\ and Jayne M. Zajicek ${ }^{3}$
}

ADDITIONAL INDEX WORDs. Carya illinoinensis, pecan varieties, market survey

Summary. A study was conducted among the attendees of the Annual Texas Master Gardener Conference held in College Station, TX, in May 2006. Participants were asked to complete a 31-question survey to understand their knowledge of the nutritional attributes and storage guidelines of pecans (Carya illinoinensis). A total of 177 attendees completed the survey, corresponding to $32.2 \%$ of the total number of conference attendees. Participants were asked to complete the survey to test their nutritional knowledge, purchasing attitude, consumption, and storage preferences of pecans ( 23 questions). The remaining eight questions requested biographical and demographical information. Results revealed that taste was the main reason people ate pecans followed by the perception of eating something healthy. Over four-fifths of survey respondents knew that pecans contain heart-healthy fats and proteins. Approximately one-half of the respondents were aware that pecans are a source of minerals and antioxidants. However, $86.9 \%$ of the respondents believed that consuming pecans could lead to an increase in the levels of low-density lipoprotein ("bad") cholesterol, which is opposite of what was reported by clinical studies. Over one-third of the respondents did not think that pecans require refrigeration to maintain flavor. Moreover, over half of the respondents did not believe that pecans store better if kept in the shell. Although the sample was limited because it was one of convenience, in general, respondents had good eating habits and a very positive attitude toward pecans. However, more educational programs are necessary to inform them about the health properties and proper storage methods of pecans.

$\mathrm{T}$ he pecan is the only tree nut with commercial importance that is native to North America and is an important nut crop

\footnotetext{
${ }^{1}$ Assistant Professor, Texas A\&M University, Vegetable and Fruit Improvement Center, Department of Horticultural Sciences, TAMU 2133, College Station, TX 77843-2133

${ }^{2}$ Associate Professor, Department of Agriculture, Texas State University, San Marcos, TX 78666

${ }^{3}$ Professor, Texas A\&M University, Department of Horticultural Sciences, College Station, TX 77843 2133

${ }^{4}$ Corresponding author. E-mail: 1-lombardini@
} tamu.edu. contributing to the agricultural economy and history of the United States. It has been used for centuries by Native Americans (Hall, 2000) and is an important tree grown for its edible nuts and timber. In 2006, the U.S. pecan production was 206 million $\mathrm{lb}$ deriving from stands of both native and improved varieties, with a total crop value of $\$ 321$ million [U.S. Department of Agriculture (USDA), 2007]. Pecan production fluctuates greatly from year to year as a result of physiological and environmental causes (Conner and Worley, 2000; Wood, 1990), and, consequently, average in-shell pecan prices vary greatly. Price of in-shell nuts has reached a record price of $\$ 1.76 / \mathrm{lb}$ in 2004 and dropped to $\$ 1.18 / \mathrm{lb}$ in 2007 (USDA, 2008).

Over 1000 different pecan varieties have been described (Thompson and Young, 1985); however, $\approx 57 \%$ of improved acreage is composed of only four varieties (Stuart, Western Schley, Desirable, and Wichita) and $\approx 90 \%$ by 33 varieties (Thompson, 1990). In recent years, other varieties such as Pawnee have been extensively planted in newly established orchards; however, official data are not available (T.E. Thompson, pers. comm.).

When pecan fruit are physiologically mature, the shucks surrounding the nuts split, trees can be shaken, and the nuts harvested. After harvest, pecans can be sold in the shell or processed. Processing involves mechanically washing and sanitizing, cracking, and separating kernels from the shells (shelling). The shelling process accelerates the oxidation process, thus reducing the shelf life of pecans (Baldwin and Wood, 2006). Rancidity and development of off-flavors are common in pecan kernels when they are not stored properly as a result of the high content of oil (Worley, 1994). It is therefore very important for retailers and consumers to follow certain guidelines to maintain flavor, color, and texture of pecan kernels. Controlling storage temperature is the single most important strategy for extending shelf life of shelled or in-shell pecans (Santerre, 1994).

Pecan kernels can be sold as whole, pieces, or meal and are commonly used as an ingredient for desserts, candies, or ice cream, but, until recently, they were not considered of value for their nutritional attributes.

\begin{tabular}{llll}
\hline $\begin{array}{l}\text { Units } \\
\begin{array}{l}\text { To convert U.S. to SI, } \\
\text { multiply by }\end{array}\end{array}$ & U.S unit & SI unit & $\begin{array}{l}\text { To convert SI to U.S., } \\
\text { multiply by }\end{array}$ \\
\hline 0.4536 & $\mathrm{lb}$ & $\mathrm{kg}$ & 2.2046 \\
28.3495 & $\mathrm{oz}$ & $\mathrm{g}$ & 0.0353
\end{tabular}

Hortectinotogy 'July-September 2008 18(3) 
Lately, however, pecan kernels have been observed to be beneficial for human health in numerous ways. They improve the serum lipid profile and may play an important role in reducing the risk for heart disease (Rajaram et al., 2000, 2001). These beneficial properties are likely the result of their high monounsaturated fatty acid content (Rajaram et al., 2001). Most recently, they have been identified as having phenolic compounds (Villarreal et al., 2007; Wu et al., 2004), which, according to several studies (Mertens-Talcott and Percival, 2005; Tam et al., 2006), act as antioxidants and have the ability to lower the incidence of chronic diseases such as Alzheimer's disease, Parkinson's disease, some types of cancer, and other degenerative diseases. Although the content in antioxidants is not reported by the USDA as a category in the National Nutrient Database (USDA, 2006), several studies indicated that pecans are a good source of this important group of phytochemicals (Chun et al., 2002; Kornsteiner et al., 2006; Wu et al., 2004). Wu et al. (2004) reported the antioxidant capacity of over 100 different kinds of foods across the United States. Several nuts, according to this study, ranked among the foods with high antioxidant capacity with pecans being the kind with the highest antioxidant capacity in the nut group. Varieties differ in their content of antioxidants, although very few varieties have been thoroughly investigated (Villarreal et al., 2007).

Despite these positive facts about pecans, per capita consumption in the United States averages only $0.49 \mathrm{lb}$ of kernels annually, which is slightly lower than walnut consumption $(0.53$ lb) but less than half than that of almonds (1.01 lb) (USDA, 2007). Regardless of increased competition from almonds, and, to a lesser extent, walnuts, pecan consumption has remained relatively stable over the past 30 years (USDA, 2007).

The recent discoveries of the health attributes of pecan kernels have prompted pecan growers' associations to start marketing programs to promote pecan consumption and to inform the consumers about the proper ways to store pecan kernels to maintain flavor and health attributes (National Pecan Shellers Associationn, 2007; Texas Pecan Board, 2007).
The objective of the present study was to survey consumers' knowledge of the nutritional attributes, storage guidelines, and their preferences of consumption and use. Results from the present study will be used to develop more marketing strategies to inform consumers about health benefits related to the consumption of pecans.

\section{Materials and methods}

SAMPLE POPULATION. The study was conducted during the Annual Texas Master Gardener Conference held at Texas A\&M University, College Station in May 2006. Surveys were distributed at the entrance to the hall used for the inaugural session of the conference. A total of 177 persons completed the survey, corresponding to $32.2 \%$ of the total number of conference attendees (550). The population sample used for the present study was chosen because of ease of availability but cannot be considered a random sample. Therefore, conclusions drawn cannot necessarily be generalized to the overall population.

Instrumentation. The survey was modeled after similar instruments (Boyer et al., 2002; Gold et al., 2004) and was reviewed and evaluated by experts in the field of horticulture, fruit and nut production, and postharvest technology. The survey protocol and instrument were also reviewed and approved by the Human Subjects' Protection Program at Texas A\&M University before being initiated. The questionnaire was divided into two sections; section I consisted of eight questions aimed at gathering biographical and demographical information. Section II included 23 questions/statements on familiarity with the pecan tree (four questions), healthy eating habits (three questions), knowledge of pecan nutritional value (three questions), purchasing/storing attitude toward pecans (five questions), knowledge of varietal differences in pecans (three questions), and consumption preferences for pecans (five questions) (Table 1 ).

A Cronbach's alpha reliability test for the knowledge section of the questionnaire resulted in a coefficient of 0.6831 showing it to have an acceptable level of internal consistency (Sapp and Jensen, 1997).
Data analysis. Frequencies and analysis of variance were obtained using SPSS (v12 for Windows; SPSS, Chicago).

\section{Results}

Demographics. Demographic data indicated that the majority of the participants in the study were white (96.5\%) and mostly women (74.6\%) (data not shown). More than half of the participants were married with no children followed by $26.6 \%$ of participants who were married and had children. The most frequently represented age group was 50 years old or more (82.4\%). Overall, participants older than 40 years accounted for $92.6 \%$ of the total. The population sample used in the survey was highly educated with $98.4 \%$ of the participants having some college education $(22.2 \%)$, a college degree $(26.1 \%)$, some graduate/professional school (13.6\%), completed graduate/professional school $(34.1 \%)$, or trade/technical/vocational school (2.3\%). More than half of the participants had grown up in Texas (60.1\%). Overall, $96.6 \%$ of the participants had grown up in the United States. Nearly $60 \%$ of the participants reported household income levels of $\$ 75,000$ or more $(59.1 \%)$. When asked in what type of area they grew up, $30 \%$ of the respondents indicated "rural/farm/ ranch environment," whereas almost half of the participants grew up in cities with populations over 10,000 (47.7\%).

Familiarity WITH PECAN TREe. Almost every surveyed person knew what a pecan tree looked like $(97.2 \%)$ (Table 1). Additionally, $62.2 \%$ of respondents indicated that there were pecan trees around the house where they grew up. One-third $(33.6 \%)$ of respondents said that those pecan trees were actually regularly maintained with irrigation, fertilization, and harvest practices. The majority $(43.1 \%)$, however, indicated that nothing was done to those trees. One respondent out of four indicated that they harvested the nuts from their trees.

Healthy eating habits. These three questions did not have specific reference to pecans, but aimed at sampling the degree of knowledge and the attitude that participants had toward eating healthy food. 
Table 1. Statements and questions included in section II of the questionnaire for Texas Master Gardeners participating in the pecan preferences and knowledge survey.

\begin{tabular}{|c|c|c|}
\hline Question/statement & $\begin{array}{c}\text { Frequency } \\
\text { (no.) }\end{array}$ & $\begin{array}{c}\text { Frequency } \\
(\%)\end{array}$ \\
\hline \multicolumn{3}{|l|}{ Do you know what a pecan tree looks like? } \\
\hline Yes & 172 & 97.2 \\
\hline No & 5 & 2.8 \\
\hline \multicolumn{3}{|l|}{ Do you harvest your own pecans? } \\
\hline Yes & 44 & 25.0 \\
\hline No & 133 & 75.0 \\
\hline \multicolumn{3}{|l|}{$\begin{array}{l}\text { If you know what a pecan tree looks like, } \\
\text { were there any near your house? }\end{array}$} \\
\hline Yes & 115 & 62.2 \\
\hline No & 55 & 29.7 \\
\hline \multicolumn{3}{|l|}{$\begin{array}{l}\text { If there were pecan trees near your house, } \\
\text { were they regularly maintained } \\
\text { (irrigated, fertilized, harvested, and so on)? }\end{array}$} \\
\hline Yes & 46 & 33.6 \\
\hline No & 59 & 43.1 \\
\hline I do not know & 31 & 22.6 \\
\hline \multicolumn{3}{|l|}{ Do you pay attention to what you eat? } \\
\hline Always & 90 & 48.6 \\
\hline Very often & 67 & 36.2 \\
\hline Sometimes & 27 & 14.6 \\
\hline Rarely & 1 & 0.5 \\
\hline Never & 0 & 0.0 \\
\hline \multicolumn{3}{|l|}{$\begin{array}{l}\text { How many servings of fruit and vegetables } \\
\text { do you eat most days? }\end{array}$} \\
\hline None & 0 & 0.0 \\
\hline 1 & 16 & 8.6 \\
\hline 2 & 20 & 10.8 \\
\hline 3 & 48 & 25.9 \\
\hline 4 & 49 & 26.5 \\
\hline 5 & 26 & 14.1 \\
\hline More than 5 & 26 & 14.0 \\
\hline \multicolumn{3}{|l|}{$\begin{array}{l}\text { Do you read the nutrition facts label printed } \\
\text { on the food packages that you consume? }\end{array}$} \\
\hline Always & 48 & 26.1 \\
\hline Very often & 85 & 46.2 \\
\hline Sometimes & 41 & 22.3 \\
\hline Rarely & 8 & 4.3 \\
\hline Never & 2 & 1.1 \\
\hline \multicolumn{3}{|l|}{ Pecans contain ${ }^{\mathrm{z}}$ : } \\
\hline Antioxidants & 102 & 58.6 \\
\hline Fats & 155 & 83.8 \\
\hline Vitamin E & 58 & 33.3 \\
\hline Sugars & 48 & 27.6 \\
\hline Proteins & 142 & 81.6 \\
\hline Minerals such as magnesium, zinc, and copper & 94 & 54.0 \\
\hline \multicolumn{3}{|l|}{$\begin{array}{l}\text { Pecans can increase the levels of "bad" } \\
\text { cholesterol (low-density lipoprotein) }\end{array}$} \\
\hline True & 153 & 86.9 \\
\hline False & 23 & 13.1 \\
\hline \multicolumn{3}{|l|}{ Pecans contain "heart-healthy" fats } \\
\hline True & 171 & 96.6 \\
\hline False & 6 & 3.4 \\
\hline \multicolumn{3}{|l|}{ Pecans ${ }^{z}$ : } \\
\hline Should be refrigerated to maintain flavor & 109 & 63.0 \\
\hline $\begin{array}{l}\text { Store better while still in-shell compared } \\
\text { with shelled ones }\end{array}$ & 75 & 43.4 \\
\hline
\end{tabular}

(Continued on next page)
Approximately half of the participants $(48.6 \%)$ indicated that they always paid attention to what they eat, whereas $36.2 \%$ said that they did very often (Table 1). Most participants stated that they consumed either three $(25.9 \%)$ or four $(26.5 \%)$ servings of fruit and vegetables on most days; $14.1 \%$ ate at least five, and another $14.0 \%$ ate more than five. A small fraction of respondents $(8.6 \%)$ indicated that they consumed only one serving per day. Most participants were accustomed to reading nutrition facts labels: $26.1 \%$ read it "always," $46.2 \%$ "very often," and $22.3 \%$ read the label "sometimes." Two participants $(1.1 \%)$ said that they never read the nutrition label.

KNOWLEDGE OF NUTRITIONAL PROPERTIES OF PECANS. Over fourfifths of survey respondents $(83.8 \%)$ knew that pecans contain fats (Table $1)$, and a similar portion $(81.6 \%)$ indicated that pecans are a source of protein. Approximately half of the respondents knew that pecans are a source of minerals (54\%) and antioxidants $(58.6 \%)$. Exactly one-third of survey participants knew that pecans have vitamin $\mathrm{E}$ and approximately one-fourth $(27.6 \%)$ indicated that pecans contain sugars. The majority of the respondents thought that pecans contain heart-healthy fats (96.6\%). However, $86.9 \%$ of the respondents also believed that consuming pecans could increase their levels of low-density lipoprotein ("bad") cholesterol.

P U R C H A S IN G / S T O R I N G ATTITUDE TOWARD PECANS. Over Onethird $(37.0 \%)$ of the respondents did not think that refrigeration helps retain flavor of pecans (Table 1 ). Also, more than half $(57.6 \%)$ did not believe that pecans store better if kept in-shell. Despite this lack of knowledge about the proper storage method for pecans, most respondents $(90.8 \%)$ knew that freezing pecans can help maintain the flavor for up to 2 years.

Most respondents (62.9\%) purchased pecans between two and six times per year. A few (9.4\%) purchased them on a monthly basis, and some (18.8\%) did only once per year. Three of four respondents bought pecans during the holiday season and $54 \%$ of them purchased during harvest season (September to December). A few respondents (17.7\%) were 
Table 1. (Continued) Statements and questions included in section II of the questionnaire for Texas Master Gardeners participating in the pecan preferences and knowledge survey.

\begin{tabular}{|c|c|c|}
\hline Question/statement & $\begin{array}{l}\text { Frequency } \\
\text { (no.) }\end{array}$ & $\begin{array}{l}\text { Frequency } \\
\quad(\%)\end{array}$ \\
\hline $\begin{array}{l}\text { Can be stored up to } 2 \text { years and maintain } \\
\text { flavor if frozen }\end{array}$ & 157 & 90.8 \\
\hline \multicolumn{3}{|l|}{$\begin{array}{l}\text { How often do you, or someone on your } \\
\text { family, buy pecans? }\end{array}$} \\
\hline Weekly & 1 & 0.6 \\
\hline Monthly & 16 & 9.4 \\
\hline Two to 6 times a year & 107 & 62.9 \\
\hline Once a year & 32 & 18.8 \\
\hline Never & 14 & 8.2 \\
\hline Other & 0 & 0.0 \\
\hline \multicolumn{3}{|l|}{$\begin{array}{l}\text { What reasons would you contribute to } \\
\text { purchasing pecans? }\end{array}$} \\
\hline It is harvest time and I know they are fresh & 99 & 54.7 \\
\hline Holiday season & 136 & 75.1 \\
\hline Promotion from grocery/retail/or market & 32 & 17.7 \\
\hline $\begin{array}{l}\text { Marketing advertising (radio, newspaper, } \\
\text { TV commercial in informative piece) }\end{array}$ & 6 & 3.3 \\
\hline Other & 49 & 27.1 \\
\hline I do not buy pecans & 14 & 7.7 \\
\hline \multicolumn{3}{|l|}{$\begin{array}{l}\text { If you purchase pecans, where do you } \\
\text { usually purchase them? }\end{array}$} \\
\hline Farmer's market & 43 & 23.8 \\
\hline Pecan producer/orchard & 72 & 39.8 \\
\hline Roadside fruit and vegetable stand & 29 & 16.0 \\
\hline Texas A \& M Aggie pecan sale & 11 & 6.1 \\
\hline Grocery store & 116 & 64.1 \\
\hline Phone/mail/Internet order & 8 & 4.4 \\
\hline Other & 43 & 23.8 \\
\hline I do not buy pecans & 16 & 8.8 \\
\hline \multicolumn{3}{|l|}{ If you buy pecans, how do you mainly buy them? ${ }^{z}$} \\
\hline In-shell & 42 & 23.1 \\
\hline Cracked shell & 32 & 17.6 \\
\hline Shelled (halves) & 136 & 74.7 \\
\hline Pieces & 84 & 46.2 \\
\hline Meal & 7 & 3.8 \\
\hline $\begin{array}{l}\text { Prepared (chocolate covered, roasted, } \\
\text { spiced, and so on) }\end{array}$ & 26 & 14.3 \\
\hline Other & 4 & 2.2 \\
\hline I do not buy pecans & 12 & 6.6 \\
\hline \multicolumn{3}{|l|}{$\begin{array}{l}\text { If you prepare pecans, how do you mainly } \\
\text { prepare them? }\end{array}$} \\
\hline Raw snack & 112 & 61.9 \\
\hline Semiprepared snack (roasted, salted, spiced) & 74 & 40.9 \\
\hline Ingredients in food dishes & 160 & 88.4 \\
\hline Other & 8 & 4.4 \\
\hline I do not use pecans & 4 & 2.2 \\
\hline $\begin{array}{l}\text { List any other ways you may use pecans } \\
\text { in your everyday life }\end{array}$ & 112 & 61.9 \\
\hline \multicolumn{3}{|l|}{$\begin{array}{l}\text { There are many different pecan varieties } \\
\text { that I can choose from }\end{array}$} \\
\hline True & 164 & 93.7 \\
\hline False & 10 & 5.7 \\
\hline \multicolumn{3}{|l|}{$\begin{array}{l}\text { Do you pay attention to the pecan variety } \\
\text { that you buy? }\end{array}$} \\
\hline Yes & 67 & 37.8 \\
\hline No & 110 & 62.2 \\
\hline
\end{tabular}

(Continued on next page) stimulated by promotion at the point of sale, but only $3.3 \%$ thought that marketing advertising was influential in their decision. The preferred place for purchasing pecans was the grocery store $(64.1 \%)$ followed by the pecan producer's orchard $(39.8 \%)$, farmer's markets $(23.8 \%)$, and roadside fruit and vegetable stands (16\%). Most respondents preferred to buy shelled halves $(74.7 \%)$ and pieces (46.2\%). In-shell and cracked pecans were bought by $23.1 \%$ and $17.6 \%$ of the respondents, respectively. An additional $14.3 \%$ of the respondents bought pecans in prepared form (chocolate-covered, roasted, and so on).

KNOWLEDGe OF VARIETAL DIFFERENCES IN PECANS. Over ONethird of respondents $(38.2 \%)$ paid attention to the variety when they purchased pecans. Taste and size were the main reasons why they did pay attention, indicated by $50.3 \%$ and $39.9 \%$, respectively, of total respondents. Other reasons for which respondents preferred certain varieties versus others were appearance/ color $(20.3 \%$ of respondents), availability (19.6\%), and familiarity (13.1\%).

Purchasing behavior for PECANS. Pecans are a very popular ingredient in food dishes, as indicated by $88.4 \%$ of respondents. However, many also consumed them as a raw or semiprepared snack $(61.9 \%$ and $40.9 \%$, respectively). Among the other methods of consumption listed, some respondents indicated that they used them as an ingredient for baking and as something to add to cereal, yogurt, oatmeal, and salads. Taste was definitely the main reason people ate pecans $(93.2 \%)$ followed by the consciousness of eating something healthy $(54.5 \%)$. Approximately onethird of respondents (35.2\%) listed quality as one of the reasons for consumption, whereas availability was sometimes a determining cause $(30.7 \%)$. Knowing that pecans are locally grown induced consumption in one of four respondents.

Many participants showed interest in receiving information about cooking with pecans $(71.1 \%)$, nutritional properties $(55.3 \%)$, and storing guidelines $(52.2 \%)$. Some also indicated that they would like to know more about using pecan trees in the landscape $(26.4 \%)$, variety 
Table 1. (Continued) Statements and questions included in section II of the questionnaire for Texas Master Gardeners participating in the pecan preferences and knowledge survey.

\begin{tabular}{|c|c|c|}
\hline Question/statement & $\begin{array}{l}\text { Frequency } \\
\text { (no.) }\end{array}$ & $\begin{array}{l}\text { Frequency } \\
(\%) \\
\end{array}$ \\
\hline \multicolumn{3}{|l|}{$\begin{array}{l}\text { If you do pay attention to the pecan variety } \\
\text { that you buy, reasons include }\end{array}$} \\
\hline Size & 61 & 39.9 \\
\hline Taste & 77 & 50.3 \\
\hline Availability & 30 & 19.6 \\
\hline Familiarity & 20 & 13.1 \\
\hline Appearance/color & 31 & 20.3 \\
\hline I do not pay attention & 48 & 31.4 \\
\hline \multicolumn{3}{|l|}{$\begin{array}{l}\text { What are the three main reasons } \\
\text { why you eat pecans? }\end{array}$} \\
\hline Taste & 164 & 93.2 \\
\hline Quality & 62 & 35.2 \\
\hline Locally grown & 45 & 25.6 \\
\hline Ease of preparation & 27 & 15.3 \\
\hline They are healthy & 96 & 54.5 \\
\hline Price & 11 & 6.3 \\
\hline Availability & 54 & 30.7 \\
\hline Other & 9 & 5.1 \\
\hline I do not eat pecans & 7 & 4.0 \\
\hline \multicolumn{3}{|l|}{$\begin{array}{l}\text { Which ones of the following informational } \\
\text { sheets about pecans would you like } \\
\text { to read or receive? }\end{array}$} \\
\hline Cooking and preparation & 113 & 71.1 \\
\hline Nutritional properties & 88 & 55.3 \\
\hline Tree growth and production & 35 & 22.0 \\
\hline Use of pecan trees in the landscape & 42 & 26.4 \\
\hline List of retail stores/producers & 27 & 17.0 \\
\hline Storing guidelines & 83 & 52.2 \\
\hline Informational sheet about & & \\
\hline variety characteristics & 41 & 25.8 \\
\hline \multicolumn{3}{|l|}{$\begin{array}{l}\text { The average U.S. per-capita consumption } \\
\text { of pecans is } \approx 8 \mathrm{oz}^{\mathrm{y}} \text { of pecans per year. } \\
\text { What are the main reasons why you } \\
\text { do not eat more pecans? }\end{array}$} \\
\hline Price & 57 & 35.2 \\
\hline They contain too much fat & 18 & 11.1 \\
\hline I am concerned about my cholesterol level & 10 & 6.2 \\
\hline I am not always happy with the quality & 23 & 14.2 \\
\hline I can find good pecans only & & \\
\hline during the holidays & 22 & 13.6 \\
\hline I already eat plenty and I do not need to eat more & 66 & 40.7 \\
\hline I am allergic to nuts & 0 & 0 \\
\hline Other & 24 & 14.8 \\
\hline I do not eat pecans & 3 & 1.9 \\
\hline
\end{tabular}

${ }^{\mathrm{z}}$ Multiple answers permitted.

${ }^{\mathrm{y}} 1 \mathrm{oz}=28.3495 \mathrm{~g}$.

characteristics $(25.8 \%)$, tree growth and production $(22.0 \%)$, and retail stores and producers $(17.0 \%)$.

The last question of the survey asked why participants did not eat more pecans. Although some (40.7\%) indicated that they already ate plenty, approximately one-third of the respondents listed price as the main reason why they did not eat more pecans. Additionally, respondents indicated that they were not always happy with the quality $(14.2 \%)$, that it was difficult to find good pecans outside of the holiday season $(13.6 \%)$, and that they were concerned about the elevated fat content of pecans (11.1\%) and about the possible consequences on their own cholesterol level $(6.2 \%)$.

Correlation analysis. Significant gender differences were observed in the number of servings of fruit and vegetables consumed everyday $(P=0.026)$, with $59.1 \%$ of women consuming four or more servings per day versus $42.2 \%$ of men (Table 2). The percentage of men who read the nutrition facts label "very often" or "always" was smaller $(P=0.020)$ than that of women $(60.0 \%$ versus $76.3 \%$, respectively); also, $4.4 \%$ of men never read the nutrition label, whereas all women read it at least "rarely." More men $(46.5 \%)$ than women $(21 \%)$ thought that pecan kernels contained sugar $(P$ $=0.001)$. More women than men (20.3\% versus $11.1 \%)$ bought pecans from a farmer's market when compared with other places $(P=0.040)$. However, $36.4 \%$ of men declared harvesting their own pecans versus $20.8 \%$ of women $(P=0.038)$. Women $(61.4 \%)$ indicated that they did not pay attention to the variety when they purchased pecans, but men paid less attention than women ( $10.3 \%$ versus $38.6 \%, P=0.001)$. However, if they did pay attention, more men than women $(30.8 \%$ versus $7.0 \%, P=0.000)$ indicated that their purchase was driven by familiarity with the variety. Three of four women $(75.8 \%)$ had interest in reading or receiving informational sheets on cooking and meal preparation using pecans, whereas only $56.4 \%$ of men expressed that request.

Educational level of respondents had an impact on two of the survey statements (data not shown). All respondents with either a high school diploma or a general education diploma indicated that they would have liked to receive informational sheets about the use of pecan trees in the landscape, whereas such a request was indicated by $16.7 \%$ to $50.0 \%$ of respondents with a higher educational level. All respondents with either some high school or some graduate/professional school pointed out that they did not eat more pecans because they were concerned about their cholesterol level, whereas the issue was not very important for respondents with some college, college, graduate school, or technical school diploma $(14.3 \%, 4.8 \%, 11.7 \%$, and $25.0 \%$, respectively).

Household income was related to the use of pecans as an ingredient in food dishes as over $85.7 \%$ of the respondents making more than 
Table 2. Analysis of variance comparison of participants' gender and their eating habits, pecan preferences, and knowledge for Texas Master Gardeners participating in the survey.

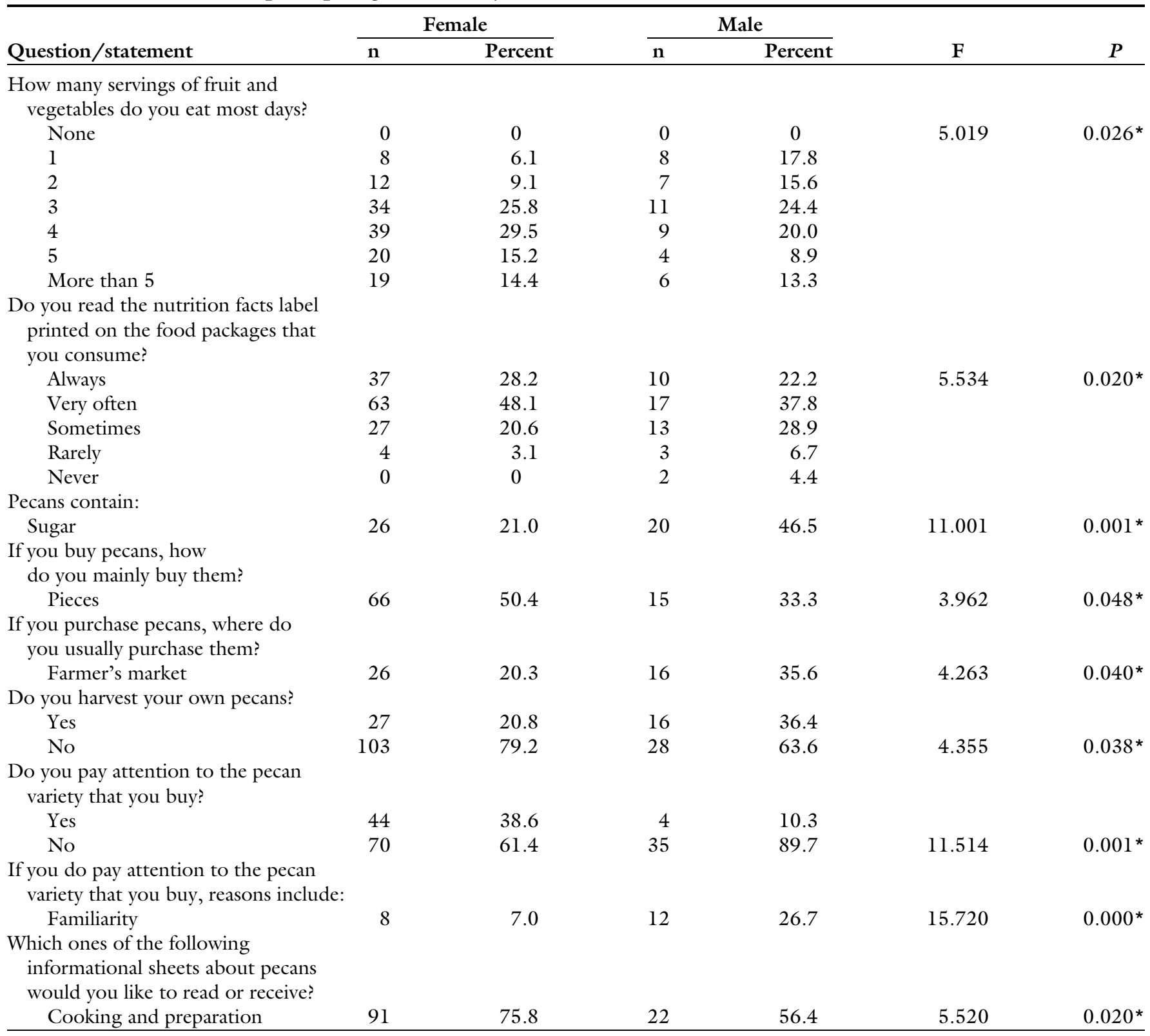

*Statistically significant at $P \leq 0.05$.

$\$ 30,000 /$ year indicated (data not shown). There was a general decrease in choosing pecans based on their variety as the household income increased. All respondents making less than $\$ 20,000 /$ year indicated that the variety choice is based on taste, whereas only approximately onethird of respondents making more than $\$ 75,000 /$ year so indicated.

Over $84.2 \%$ of the respondents that grew up in a city, metropolitan area, or major metropolitan area ate pecans because they were locally grown compared with $62.2 \%, 61.5 \%$, and $45.5 \%$ of respondents that grew up in a rural, small town, or town area, respectively (data not shown). Respondents that grew up in a small town or town also preferred to receive informational sheets on cooking and preparation versus an average of $16.6 \%$ of respondents who grew up in other places. All respondents that grew up in a metropolitan area or major metropolitan area did not eat more pecans because of their concern for increased cholesterol levels. Cholesterol was not a major concern for people that grew up in a town $(18.2 \%)$ and even less for those that grew up in a rural area, small town, or city $(2.2 \%, 7.1 \%$, and $3.1 \%$, respectively).

\section{Conclusions}

This research examined consumer preferences toward pecans and their knowledge of nutritional attributes. The results represent a baseline to develop new and more targeted research regarding marketing programs aimed at increasing nutritional properties, value added, and consumption of this important North American crop.

Pecan's native distribution extends from northern Illinois and southeastern Iowa to the Gulf of Mexico coast of the United States (Thompson and Grauke, 1991). Thus, it was not surprising that many 
respondents knew about pecans considering that $81 \%$ of the respondents were from states where pecan is native (Alabama, Arkansas, Kansas, Illinois, Louisiana, Missouri, Mississippi,Oklahoma, and Texas) or has been introduced (Arizona, California, Georgia, Florida, New Mexico, North Carolina, and South Carolina) (Thompson and Grauke, 1991).

In general, respondents had good eating habits as indicated by the number of servings of fruit and vegetables consumed on a daily basis. Also, many of them were interested in reading the nutrition facts label printed on food products. Healthy attributes of pecans was the second most important decision factor in determining why people ate pecans preceded only by taste. Most respondents had, in fact, good knowledge about the nutritional content of pecans and knew that pecans are rich in fats, antioxidants, proteins, and vitamin E. The USDA National Nutrient Database for Standard Reference (USDA, 2006) reported that pecans contain $\approx 72 \%$ fat $(62.4 \%$ in the unsaturated and $6.2 \%$ in the saturated form), $9 \%$ protein, $4 \%$ sugar, $1.4 \%$ vitamin $\mathrm{E}$ (in the form of $\alpha$-tocopherol), and less than $1 \%$ minerals (calcium, iron, magnesium, phosphorus, potassium, sodium, zinc, copper, and manganese). Many respondents indicated, correctly, that pecans contain sugars and minerals, although their content is not very elevated (USDA, 2006). The biggest misconception among the survey respondents was that eating pecans could lead to increased cholesterol levels, which is actually the opposite of what emerged from recent studies (Rajaram et al., 2000, 2001). Rajaram et al. (2001) reported that when participants were given a pecanenriched diet, their total and lowdensity lipoprotein cholesterol was twice as low as the levels of those individuals who followed the American Heart Association Step I diet (34\% energy from total and $15 \%$ from saturated fat). Despite the misconception about cholesterol levels, almost all respondents (96.6\%) knew that pecans contain mainly unsaturated fatty acids, frequently known as "heart-healthy" fats.

A good portion of participants were not aware that refrigeration helps maintain flavor in pecans and that in-shell pecans store better than shelled ones. This shows that the public does not know the benefits of proper handling and need to be educated on storing pecans.

Price appeared to be a factor in determining purchasing of pecans for one-third of the respondents. Pecan price has increased steadily in the past few years (reaching $\$ 7$ to $8 / \mathrm{lb}$ for retail shelled pecans) and this increase is a cause of concern within the industry. More research is needed to more accurately determine the impact of price on consumers' purchasing behavior.

The reasons given by respondents of this study for eating pecans were slightly different from those reported in a previous study conducted in Missouri to survey consumers' preferences for chinese chestnut (Castanea mollissima), eastern black walnuts (Juglans nigra), and pecans (Gold et al., 2004). Although here the three top reasons were taste, consciousness of eating a healthy product, and quality, in the Missouri study, $79 \%$ of respondents indicated that taste was the strongest attribute that influenced their decision in purchasing pecans followed by quality $(77 \%)$, nutrition-diet-health properties $(62 \%)$, ease of preparation $(60 \%)$, locally grown product $(54 \%)$, and price (46\%) (Gold et al., 2004).

Similar to the case with chestnuts (Gold et al., 2004), the present study showed that pecan consumption was very strongly associated with the holiday season. Changing this tradition could considerably increase per-capita consumption of this nut. However, to convince the consumers that pecans can be a year-round food, it will be important to promote pecans by including them in recipes that are more appropriate for spring and summer use. A necessary aspect of achieving this objective will be to show the public and retailers that if pecans are stored under the proper conditions of temperature and relative humidity, they can taste as fresh even if consumed months after harvest. Although the results presented here indicated a very positive attitude of consumers toward pecans, the general picture would likely appear very different had the survey been conducted in areas where pecans are not grown (such as the midwestern or northwestern United States) and are not so familiar to the public as in the population sample surveyed here. Before developing nationwide marketing and educational programs, it will be necessary to expand this type of survey to other areas and other demographic groups to broaden their efficacy.

\section{Literature cited}

Baldwin, E.A. and B. Wood. 2006. Use of edible coating to preserve pecans at room temperature. HortScience 4l: 188-192.

Boyer, R., T.M. Waliczek, and J.M. Zajicek. 2002. The Master Gardener program: Do benefits of the program go beyond improving the horticultural knowledge of the participants? HortTechnology 12:432-436.

Chun, J., J. Lee, L. Ye, and R.R. Eitenmiller. 2002. Effects of variety and crop year on tocopherols in pecans. J. Food Sci. 67:1356-1359.

Conner, P.J. and R.E. Worley. 2000. Alternate bearing intensity of pecan cultivars. HortScience 35:1067-1069.

Gold, M., M.M. Cernusca, and L. Godsey. 2004. Consumer preferences for chestnuts, eastern black walnuts, and pecans. Hort Technology 14:583589 .

Hall, G.D. 2000. Pecan food potential in prehistoric North America. Econ. Bot. 54:103-112.

Kornsteiner, M., K.H. Wagner, and I. Elmadfa. 2006. Tocopherols and total phenolics in 10 different nut types. Food Chem. 98:381-387.

Mertens-Talcott, S.U. and S.S. Percival. 2005. Ellagic acid and quercetin interact synergistically with resveratrol in the induction of apoptosis and cause transient cell cycle arrest in human leukemia cells. Cancer Lett. 218:141-151.

National Pecan Shellers Association. 2007. Pecans. So good. So good for you. 12 Dec. 2007. <http://www. ilovepecans.org $/>$.

Rajaram, S., K. Burke, B. Connell, T. Myint, and J. Sabaté. 2001. A monounsaturated fatty acid-rich pecan-enriched diet favorably alters the serum lipid profile of healthy men and women. J. Nutr. 131:2275-2279.

Rajaram, S., T. Myint, B. Connell, K. Burke, and J. Sabaté. 2000. Effect of pecan rich diet on serum lipids and lipoproteins in healthy men and women. FASEB J. 14:A293 (abstr.). 
Santerre, C.R. 1994. Pecan processing, p. 49-67. In: Santerre, C.R. (ed.). Pecan technology. Chapman \& Hall, New York, NY.

Sapp, S.G. and H.H. Jensen. 1997. Reliability and validity of nutrition knowledge and diet-health awareness tests developed from. J. Nutr. Educ. 29:6372 .

Tam, N.N.C., A. Nyska, R.R. Maronpot, G. Kissling, L. Lomnitski, A. Suttie, S. Bakshi, M. Bergman, S. Grossman, and S.-M. Ho. 2006. Differential attenuation of oxidative/nitrosative injuries in early prostatic neoplastic lesions in TRAMP mice by dietary antioxidants. Prostate 66:57-69.

Texas Pecan Board. 2007. Latest pecan news. 12 Dec. 2007. <http://www.texas pecans.org/news.html>.

Thompson, T.E. 1990. Pecan cultivars: Current use and recommendations. Pecan South 24:12-17.
Thompson, T.E. and L.J. Grauke. 1991. Pecans and other hickories (Carya). Acta Hort. 290:839-904.

Thompson, T.E. and F. Young. 1985. Pecan cultivars-Past and present. Texas Pecan Growers Assn., College Station, TX.

U.S. Department of Agriculture. 2006. National Nutrient Database for Standard Reference, Release 19. 2 Aug. 2007. <http://www.ars.usda.gov/ba/bhnrc/ ndl>.

U.S. Department of Agriculture. 2008 Noncitrus Fruits and Nuts 2007 Preliminary Summary, U.S. Dept. Agr., Natl. Agr. Stat. Serv., Fr Nt 1-3 (08). 25 Feb. 2008. <http://usda.mannlib.cornell. edu/usda/current/NoncFruiNu/ NoncFruiNu-01-23-2008.pdf>.

U.S. Department of Agriculture. 2007 Fruit and Tree Nuts Situation and Outlook Yearbook 2007. 25 Feb. 2008. $<$ http://usda.mannlib.cornell.edu/
usda/ers/FTS-yearbook / /2000s /2007/ FTS-yearbook-10-30-2007.pdf>.

Villarreal, J.E., L. Lombardini, and L. Cisneros-Zevallos. 2007. Phytochemical constituents and antioxidant capacity of different pecan [Carya illinoinensis (Wangenh.) K. Koch] cultivars. Food Chem. 102:1241-1249.

Wood, B.W. 1990. Alternate bearing of pecan, p. 180-190. In: Wood, B.W. and J.A. Payne (eds.). Pecan husbandry: Challenges and opportunities. U.S. Dept. Agr., Agr. Res. Serv. ARS-96.

Worley, R.E. 1994. Pecan physiology and composition, p. 39-45. In: Santerre, C.R. (ed.). Pecan technology. Chapman \& Hall, New York, NY.

Wu, X.L., G.R. Beecher, J.M. Holden, D.B. Haytowitz, S.E. Gebhardt, and R.L. Prior. 2004. Lipophilic and hydrophilic antioxidant capacities of common foods in the United States. J. Agr. Food Chem. 52:4026-4037. 